Article

\title{
The Enemy at the Gates: International Borders, Migration and Human Rights
}

\section{Pia Oberoi $^{1, *}$ and Eleanor Taylor-Nicholson ${ }^{2}$}

1 Office of the United Nations High Commissioner for Human Rights, United Nations Office at Geneva, CH-1211 Geneva 10, Switzerland

2 Global Alliance Against Traffic in Women, Charan Sanitwong Road, Lane 11, Bangkok, 10600, Thailand; E-Mail: etaylornicholson@gmail.com

* Author to whom correspondence should be addressed; E-Mail: poberoi@ohchr.org; Tel.: +41-22-928-9436.

Received: 21 May 2013; in revised form: 24 July 2013 / Accepted: 24 July 2013 /

Published: 31 July 2013

\begin{abstract}
This article considers contemporary border management regimes from a human rights perspective. It demonstrates how a preoccupation with border controls and enforcement has led to serious concerns for the safety and protection of migrants. As border zones have expanded, border crossing has become a more stigmatized and dangerous activity, and even as globalization has given rise to easier and faster international travel, for some, such movement has been outlawed and stigmatized. Measures to strengthen and "secure" borders have paradoxically made migrants, particularly irregular and vulnerable migrants, more at risk of violence and exploitation by non-State and State actors. Migration governance regimes at international borders are thus increasingly located within security and enforcement frameworks that pay little attention to the principles and standards of international human rights law. The paper argues that a human rights-based approach to such regimes is urgently needed, in order to address a growing human rights crisis at international borders.
\end{abstract}

Keywords: migration; immigration; border control; human rights; security; migrant smuggling; criminalization; irregular migrants; OHCHR

Abbreviations: OHCHR: Office of the High Commissioner for Human Rights 


\section{Introduction}

The language of control is a familiar one within the contemporary discourse on international migration. Across the world, governments are asserting control of their borders and of the movement of migrants across these borders. ${ }^{1}$ The border has become a "site of control", a place where the founding myths of the nation-state are invoked and reified [1]. The language used to demonstrate the need for such pervasive control is illustrative. Governments, and the popular media, in destination countries, particularly those in the global North, have declared a "war" on "illegal immigration". Such migration is said to threaten security, public services and labor markets, as well as cultural and national identity. This discourse constructs the individual migrant as the "other", an unwanted threat to the integrity of the State. As one commentator notes, "Appearing to crack down on 'unwanted immigration' is increasingly regarded by governments as essential for safeguarding social peace" ([2], p. 306).

Consequently, the territorial border, which physically and symbolically divides the citizen from the outsider, has become a central preoccupation of the modern nation-state. It has also become a powerful symbol of sovereignty. The Secretary General noted in a recent report to the Security Council, "Globalization has given rise to an exponential growth in the volume of international trade and movement of goods, money and persons. ... This unprecedented openness in trade, finance and travel has created economic growth and well-being. However, in many contexts, this rapid change has often outpaced the growth of mechanisms for national, regional and global governance, giving rise to massive opportunities for transnational organized crime and corruption to thrive and for terrorists to exploit" ([3], paras. 1-2). In a globalizing world, where the theoretical construct of sovereignty is daily breached by the movement of goods, capital, information and ideas, it is significant that the movement of people should continue to inspire often visceral reactions by States and their populations. Also significant, but often unremarked, is the fact that it is usually those who are poor and disenfranchised who feel the full force of the migration governance regimes designed to criminalize and exclude certain foreigners. Multiple layers of marginalization and discrimination accompany poor and vulnerable individuals as they attempt to migrate across borders; despite the fact that it is the poor and the socially excluded who are most in need of migration as a survival strategy ([4], p. 28).

In March 2012, the Office of the High Commissioner for Human Rights (OHCHR), in cooperation with the Global Alliance Against Traffic in Women (GAATW), held an expert meeting on the subject of "Human Rights at International Borders: Exploring Gaps in Policy and Practice" [5]. The aim of the expert meeting was to explore the human rights situation at international borders, as well as the need for enhanced human rights guidance in this respect. The participants concluded that States imagine border controls as performing one or more of the following functions: military operations against invasions and attacks against the State's sovereignty; crime prevention and law enforcement against criminal activity; or administrative practices to regulate entry and exit into the territory.

When international migration is defined primarily within the terminology of alarm, crisis and panic, the response is one of defense of the country's borders to the exclusion of other considerations (such

1 For the purposes of this paper, the term "migrant" is defined broadly to mean persons who are outside the territory of the State of which they are nationals or citizens. This could include particular categories of persons who have a more specific definition in international law, including refugees, trafficked persons and separated and unaccompanied children. Where particular categories of people are being considered, this will be made clear in the paper. 
as, for instance, the demands of domestic labor markets). In addition, the use of terminology suggesting unbearable numbers of migrants "flooding" or "swamping" the country and society tends to lead policy makers to define the problem in terms of numbers and quotas and demand containment (primarily through border control measures) as the solution. Human rights, including a focus on migrants as rights-holders, is largely absent from this paradigm.

Instead, border management paradigms are often explicitly or implicitly discriminatory, meting out different treatment to migrants on prohibited grounds, such as nationality, legal status, ethnicity, age, gender or religion. In 2001, for example, the Council of Europe was sufficiently concerned about the situation at European borders to assert that, "Everyone has the right, on arrival at the border of a member State, to be treated with respect for his or her human dignity rather than automatically considered to be a criminal or guilty of fraud" [6].

This article addresses a significant gap in the literature that was identified at the OHCHR and GAATW expert consultation, namely a comprehensive overview of the human rights concerns that arise at international borders and the contribution that the human rights framework could make to address these concerns. It first describes various key features of modern border control practices and, then, outlines human rights violations and other harms faced by migrants. It highlights as a significant concern the criminalization of irregular migration that has proliferated among States. Criminalization has pushed migrants into situations in which they are increasingly vulnerable to human rights abuses, violent crime, kidnapping, extortion or other harm. The article notes that, regardless of nationality, legal status or other grounds, all migrants at international borders are entitled to enjoyment of their fundamental human rights. In the final analysis, we argue that the international human rights framework provides valuable tools for addressing problems at borders and, as a matter of international law, trump domestic immigration enforcement and other migration governance objectives, when these collide [7].

\section{The Changing Nature of Border Controls}

Since the emergence of the modern nation-state, states have instituted border protections and limitations on who may enter and stay. These have, at times, been explicitly xenophobic in nature, such as the infamous United States Chinese Exclusion Act of 1882. However, preoccupation with border protection and surveillance has escalated dramatically in recent years and migration management has become almost single-mindedly focused on the identification, development and financing of measures that focus on the security aspects of irregular migration ([8], para. 37). This primarily applies to major and predominantly Western destination states, but these states are also exporting models of control to origin and transit states.

This new context is reflected in a number of significant developments, which are giving rise to new and more serious human rights concerns. First, border controls have been enshrined in ever more restrictive legal regimes, including expanded background checks for potential migrants, new and stricter requirements for obtaining a visa, visa quotas and tougher penalties for violating immigration laws. Restrictive domestic regimes have been supported by a proliferation of multi-lateral and bilateral dialogue platforms devoted to fighting "illegal immigration". As Wexler notes, states are increasingly

using regional consultative processes on migration to address and manage migration issues, but these 
have been criticized for their generally exclusive and confidential nature and, also, for adopting a lowest common denominator approach to human rights, while harmonizing aggressive management practices [9].

Second, border management functions have become spatially detached from territorial borders. In today's world, the border confronts migrants in a multitude of ways: at the visa counter of a foreign embassy in their country of origin; at the check-in desk at the airport, where the carrier examines their visas; when being prevented from boarding a flight by an airport liaison officer; on board a ship that has rescued their capsizing vessel; in an airport detention center after being denied permission to enter; or as a wall physically separating their country from its neighbor. These techniques push clearance of persons to enter a state 'upstream' and into the hands of bureaucratic decision makers, limiting the extent to which a person can claim rights or challenge violations [10]. Human rights violations can take place even before people leave their country of origin, including visa regimes that are severely restrictive or even discriminatory and arbitrary, and provisions, such as carrier sanctions that interfere with the right of freedom of movement.

Third, in addition to expanding control measures outward, major Western democracies have also considerably strengthened their territorial borders, with increases in personnel and technology. The United States, for example, has increased the number of people patrolling its southern border between 1990 and 2010 by more than five-fold. In 1992, the figure was just 3,555 agents, whereas in 2010, it was more than 20,000. The budget of the U.S. Customs and Border Protection Agency grew from \$5.9 billion in 2002 and to a projected $\$ 12$ billion in 2013 [11]. The EU, in just one example of its dramatic border strengthening efforts in recent years, launched a multi-billion dollar project in Spain in 2013. The project will see drones, satellites and aerostats deployed over the southern Mediterranean to increase EU border surveillance, specifically for boats of irregular migrants [12].

Efforts to control the movement of irregular migrants have led to a plethora of, sometimes dangerous, interception methods, including interception of boats at sea and interception of migrants on their journeys through transit states. Transit countries themselves are becoming enmeshed in the protection of the borders of destination states, including through readmission agreements. These agreements require a state to readmit a migrant if he or she transited that state en route to a destination state or region. In addition, the agreements also require transit states to tighten their own border controls. A recent report, for example, details how in anticipation of EU membership, Croatia has tripled its border police to 6,000 personnel and equipped them with thermal vision cameras and infrared binoculars to identify irregular migrants travelling at night and to prevent them from transiting through Croatia to the EU [13].

Fourth, private actors, including airlines, shipping companies and private security agencies, carry out many border management functions today. These actors can operate without significant oversight, without taking human rights into account and with relative impunity if human rights violations do occur, due to commercial confidentiality agreements, a lack of effective complaint mechanisms and, often, the rapid removal of the person from the state in which the violation occurred ([14], pp. 215-41). Further, a lack of oversight and justice mechanisms at borders can encourage a culture of impunity to flourish amongst border guards and immigration officials.

Finally, a range of broader policy and administrative measures on migration, including injudicious counter-smuggling laws and measures that criminalize irregular migrants, have an impact on the 
protection of human rights at international borders. They enhance the vulnerability of migrants to abusive facilitators of movement, including smugglers and traffickers. This is exacerbated by increased restrictions on regular migration channels, particularly for low-skilled or low-wage workers, as well as for migrants in search of reunification with family members.

In sum, migration governance regimes at international borders are increasingly located within security and enforcement, rather than protection and facilitation, frameworks. The following section outlines some of the key human rights concerns arising from this approach to border management.

\section{Dying to Enter and Other Human Rights Concerns}

Increasingly, tough immigration restrictions and controls at external borders have created the conditions and incentives for migrants to turn to facilitated movement and the services of smugglers and led to a proliferation of such groups and individuals ([15], p. 9; [16]). They have also escalated the risks and raised the stakes of irregular movement, forcing migrants into dangerous modes of travel, sometimes in conditions that violate human rights. Europol has noted that, "[T]ransiting migrants [who have engaged the services of smugglers] are frequently exploited in illicit labor, thus marking a point of contact between illegal immigration and trafficking in human beings" [17].

More migrants are dying in the attempt to move. The OHCHR reported that in the first eight months of 2011, more than 1,400 people lost their lives in the sea between North Africa and Europe alone [18]. Since 1988, an astonishing 14,000 or more people are estimated to have died trying to enter the European Union [19]. Uncounted numbers of migrants, refugees and trafficked persons lose their lives when they board unseaworthy boats, smugglers leave them to die at sea or when border guards are given orders to "shoot at sight" to deter irregular migration. In other parts of the world, too, from Asia to the Americas, migrants are literally dying in their efforts to enter other countries.

Among those who survive, other irregular migrants experience injury, violence, exploitation, dehydration, hunger and illness on their journeys. Violence (sometimes lethal violence) occurs at borders, perpetrated both by State (border guards, military personnel) and non-State actors (traffickers, smugglers, airline officials and private security companies). Girls and women are especially vulnerable to all kinds of violence, including sexual violence. Medicin Sans Frontieres working with sub-Saharan African migrants travelling through Morocco has found that $39 \%$ of all migrants suffer some form of violence in this context. Almost half of women interviewed reported "that they were subjected to sexual violence during the journey, in many cases, more than once". The principle perpetrators are common criminals, smugglers and human trafficking networks. A further 59\% were assaulted in the border region between Algeria and Morocco. Although state security forces were not directly involved in the attacks, the practice of driving irregular migrants out into the desert and abandoning them there rendered them extremely vulnerable to violence and abuse at the hands of non-state actors ([20], pp. 5-7).

International borders are indeed discriminatory and dangerous places for many who arrive there, particularly those who are (or who are presumed to be) in irregular situations. At land, sea and air borders around the world, migrants experience discrimination and arbitrary decision making, which is by and large non-reviewable, particularly if carried out in remote border regions or outside the territory of the State. Unlawful profiling and disproportionate interference with the right to privacy, torture, dangerous detection and interception practices and prolonged or arbitrary detention have also been 
documented by human rights experts. Asylum seekers are effectively being prevented from access to asylum procedures. Irregular migrants attempting to enter, or suspected of entering, a country without authorization are vulnerable to human rights violations, but regular migrants may also face discrimination and abuse. In attempting to prevent migrants from engaging their human rights obligations, states can carry out collective expulsions from their territories, as well as from the high seas.

Allegations of excessive force and even assault during forced returns also highlight injury and deaths of migrants at the hands of security forces [21]. The use of non-medically justified measures or treatment, such as sedatives to facilitate deportation, is of concern. Other practices of concern include states deporting migrants into no-mans' land or merely to the vicinity of another country's border. This practice is particularly worrying in the case of unaccompanied or separated children. Independent monitoring and increased scrutiny of deportations is urgently needed. A promising practice in this regard is the use of National Preventive Mechanisms to monitor the whole process of forced return, from the removal centers through to the arrival at the airport in the destination state. Other best practices include ensuring that returns take place during the day and including a medical expert as part of the deportation monitoring team.

Detention of irregular migrants at borders is increasing around the world, particularly in transit countries (in situations of both attempted entry to and departure from transit countries). Human rights standards contain a strong presumption against detention, based on the right to liberty (Article 9(1) of the International Covenant on Civil and Political Rights (ICCPR) and Article 16(1) of the International Convention on the Protection of the Rights of Migrant Workers (ICRMW)). All persons are protected against arbitrary detention, regardless of their legal status. In its General Comment No. 8 on the Right to Liberty and Security of the Person, the Human Rights Committee has confirmed that Article 9(1) of ICCPR is relevant in the circumstances of immigration control, noting that the right to control by a court of the legality of the detention, applies to all persons deprived of their liberty by arrest or detention ([22], para. 1).

Far from being used as a last resort, as befits a measure with such a drastic effect on its subject, administrative detention at borders is routine and, in some cases, mandatory. In many cases, procedural safeguards for administrative detention are fewer than for criminal detention, including a lack of measures to determine the arbitrariness of the arrest and continued detention. The use of detention at international borders is concerning, both for the lack of procedural safeguards and for poor conditions, such as denial of access to medical care, and to adequate conditions, including space, food and water, in short-term custody. Little analysis has been done into whether existing standards regulating the conditions of immigration detention are sufficient for border detention and whether states are being guided by the principle of proportionality and necessity in assessing when to use detention at borders. Alternatives to detention have also not been systematically examined, despite a lack of "empirical evidence that immigration detention deters irregular migration, or discourages persons from seeking asylum" [23].

Notwithstanding the discretion states are allowed in determining whom to admit to their territory, distinctions based on race, ethnicity, religion (commonly termed racial profiling) or health status are questionable under international human rights law. Distinctions, for example, on the basis of health are only permissible if the aim is legitimate (e.g., exclusion on the basis of HIV status can be prima facie 
arbitrary, because it is not related to a public health objective or to a public security objective) and the means used are proportionate and do not interfere with a protected right or interest (such as the right to family unity or the best interests of the child).

In addition, profiling has been criticized as a blunt instrument, which, in most cases, has a limited practical effect. In the context of counter-terrorism, despite academic disagreements about whether racial profiling constitutes discrimination within human rights law or whether non-discrimination is a derogable right, the main argument against the use of such profiling is that it is simply ineffective at achieving its given purpose. There is no reliable empirical evidence that racial profiling is an effective counter-terrorism measure and no solid theoretical reason why it should be ([24], pp. 74-95).

Further, migrants have reported arbitrary confiscation or destruction of the identity documents and property of migrants, both by private actors, such as smugglers, as well as state officials, such as border guards, in violation of human rights law. Article 17 of the International Covenant on Civil and Political Rights provides that "No one shall be subjected to arbitrary or unlawful interference with his privacy, family, or correspondence, nor to unlawful attacks on his honor and reputation." Article 14 of the Convention on the Rights of All Migrant Workers and Members of their Families (ICRMW) similarly protects the privacy of migrant workers and members of their families. Further, Article 21 of the ICRMW provides protection of the identity documents of migrant workers, asserting that, "In no case shall it be permitted to destroy the passport or equivalent document of a migrant worker or a member of his or her family."

Migrants are also subject to new technologies of surveillance at borders; database integration, as well as the collection of biometric data raise human rights concerns, such as intrusions into privacy and lack of personal data protection. Biometric data can also be sifted for religious, ethnic or racial characteristics that can be used for profiling unconnected with security or immigration concerns. Data sharing principles emphasize that individuals should know what data is being collected about them, with whom it is being shared and for what purpose. Migrants at borders are rarely able to assert this right to privacy, as border management regimes race to take advantage of technological advances to gather ever-greater quantities of data.

Finally, for all of the concerns highlighted above, access to justice is almost always a concern. Migrant victims of violence and other violations rarely have recourse to national justice institutions or other formal complaint mechanisms, especially if they are irregular. Either they are removed from the country (or prevented from entering) before they can file a claim or no such mechanisms exist or access in border regions is limited. Many immigration decisions are also made within the realm of administrative discretion and not subject to review.

\section{Irregular Migrants, Criminalization and Stigmatization}

Widespread misperceptions about the scale and nature of migration can contribute to prejudice and xenophobia and, eventually, justify increasingly harsh border management regimes. Public opinion surveys have revealed a consistent over-estimation of the absolute numbers of migrants in destination societies, belying the reality that, today, South-South migration is almost as common as South-North migration and about one-third of all migrants originate from and are living in the global South [25]. For example, a study of eight migrant receiving countries (Canada, France, Germany, Italy, the 
Netherlands, Spain, the United Kingdom and the United States) found that, in all of them, respondents were inclined to overestimate significantly the migrant population. Americans, on average, estimated a foreign-born population of $37.8 \%$, while the actual foreign-born population was a much smaller $12.5 \%$ ([26], p. xiv; [27]). The Global Migration Group has expressed its deep concern about the human rights of migrants in an irregular situation, insisting that, "The irregular situation which international migrants may find themselves in should not deprive them either of their humanity or of their rights" [7].

The principal response of the international community to irregular migration has been to criminalize irregular movement across borders. Policy frameworks at the bilateral, regional and international level regularly bracket irregular migration together with international criminal activities, like drug trafficking, money laundering and terrorism. As a result, states have increasingly turned to criminal law, which imposes fewer responsibilities for the protection of non-citizens, to provide a framework within which to control or "manage" migration.

Yet, the vast majority of irregular migrants are not criminals in the ordinary sense of the word. The criminalization of irregular migrants, for what is essentially an administrative infraction, has been widely criticized as disproportionate and counter-productive. The Working Group on Arbitrary Detention has held that "criminalizing illegal entry into a country exceeds the legitimate interest of states to control and regulate irregular immigration and leads to unnecessary detention" ([28], para. 53; [29]). The Special Rapporteur on the human rights of migrants has asserted that "[I]rregular migration is not a crime. State authorities have increasingly had recourse to the language of crime when they speak of irregular migration, with some states resorting to criminalization of irregular migration and/or of helping migrants in an irregular situation. Crossing borders may be in violation of the law, but it is an abstract violation of the law, since moving from one country to another does not per se endanger any person, nor affect any property" [30].

Further, the status of many irregular migrants is rarely static, motivations will change or adjust as migrants undertake often long and complicated journeys and many will fall in and out of a regular status along the way, as a result of administrative incoherence or human rights violations.

Related to this is the increasing difficulty of separating out neatly the various "categories" of people who arrive at international borders. Given the complex realities of human mobility today and the varied and intricate motivations for movement, a wide spectrum of legal categories of people typically arrive at borders, ranging from asylum seekers and refugees, to trafficked persons, smuggled migrants, irregular migrants and regular migrants. Many migrants will need protection, some of whom will be able to define their protection needs within conventionally accepted legal definitions, while others will fall through the gaps between legal protection regimes. Children will arrive at borders both unaccompanied and with their parents or guardians. Some will not be legally recognized as children and will be treated as adults [31]. Migrants will often "shape-change" as they move, passing through varying legal categories during their journey, and sometimes inhabiting multiple categories at the same time. They will be confronted with a bewildering array of labels and legal statuses. Some migrants will consciously seek out one or the other status; others will be unaware of the possibilities and their rights, usually until they are confronted with the need to define themselves to state authorities.

The International Council on Human Rights Policy has said that, "The fact that distinctions can be made between groups of people, however, does not mean that they are not hazardous to apply in 
practice ... [B]order or migration officials face acute difficulties in applying legal distinctions to the real experience of migrants. In practice, the choices migrants make (or are compelled to make) are such that it is frequently difficult to assert whether they are wholly smuggled or wholly trafficked, whether they chose or were compelled to leave their countries of origin, and whether they left for reasons which can fit clearly into accepted protection categories ([32], p. 14)." Some have argued that the definition of 'migrant' should take into consideration only an individual's current status in the receiving country, not how he or she got there. This recognizes the important contemporary reality that protection is often needed by migrants as a result of the situation into which they have arrived, rather than solely on the basis of the situation from which they are fleeing [33].

Responding to irregular migration, in 2000, states adopted and rapidly ratified the Protocol Against the Smuggling of Migrants by Land, Sea and Air, supplementing the United Nations Convention on Transnational Organized Crime (the Smuggling Protocol). ${ }^{2}$ There are currently 116 signatories to the Smuggling Protocol, under which states are obligated to pass laws aimed at disrupting organized criminal networks that are facilitating the illegal entry of migrants for their own profit, by criminalizing the smuggling of migrants (Article 6). States also have a positive duty under international human rights law to protect all those under their jurisdiction. Indeed, smugglers have been responsible for a range of human rights abuses against migrants who seek their services, including extortion, exploitation and violence. A broad range of actors has therefore called on states to apply appropriate sanctions against abusive smugglers and their networks and to protect migrants against abuse, by passing such laws.

However, human rights advocates have also raised concerns that some counter-smuggling measures can negatively affect human rights, both the rights of migrants themselves and of those who facilitate their movement. These negative effects include the criminalization of smuggled migrants, as well as disproportionate sanctions meted out against smugglers who have caused no harm to the migrant. From a human rights perspective, the act of smuggling itself (when the migrant does not suffer violence or other abuse) is merely a crime against the sovereignty of a country. In some cases, migrant smuggling could be a humanitarian response to assist individuals and families flee poverty, desperation and human rights violations and, where necessary, to seek asylum, comparable to the Underground Railroad in the United States during the 1800s, which smuggled people out of slavery [34].

Aggressive counter-smuggling measures and harsh border control regimes have largely failed to reduce either irregular migration or, in general, to disrupt smuggling operations. On the contrary, such controls appear to have triggered the development of increasingly sophisticated smuggling and trafficking networks, devising ever more ingenious techniques for crossing borders. Reports suggest that tight border controls encourage smugglers to charge more for their services, thereby rendering migrants more vulnerable to abusive practices. As border surveillance methods become increasingly sophisticated, smuggling and trafficking networks use ever more perilous routes to evade detection, and more migrants are wounded or die as a result. At the US-Mexico border, for instance, one report found that "[s]muggling in decades past was the business of small independent operators who helped

2 The "smuggling of migrants" refers to the procurement in order to obtain, directly or indirectly, a financial or other material benefit of the illegal entry of another person into a state of which that person is not a national or resident. Article 3 of the Protocol on the Smuggling of Migrants by Land, Sea and Air. 
migrants cross once they reached the US border. But evading US authorities has become much more difficult with increased border enforcement in recent years. At the same time, Mexico's migrant routes have become much more dangerous, controlled by drug gangs that see new moneymaking opportunities in kidnapping and extorting those who cross their territory" [35].

Smuggled migrants can therefore be at particular risk of human rights violations, at the hands of abusive smugglers or at the hands of state authorities, due to their perceived participation or collusion in a criminal enterprise. This vulnerability is exacerbated by the fact that many smuggled migrants interact with the authorities of destination or transit countries only within the border space. Migrants who are smuggled will typically be stopped at the border, or in the zone around the border, and deported for violations of immigration rules without any further questions being asked about their situation or need for human rights protection. Note, however, that the Smuggling Protocol does not preclude states from prosecuting smuggled migrants for violations of immigration laws at the same time as it protects such migrants from being penalized for the fact of being smuggled [36].

\section{A Human Rights-Based Approach to the Governance of Borders}

\subsection{The Human Rights Framework and a Rights-Based Approach}

What has been missing from the discourse of border control is a migrant-centered approach based on the human rights framework. A human rights approach is grounded in the notion that basic human rights are not a matter of charity, but of justice, and should therefore be embodied in transparent, binding standards.

The reasons for such an approach are many. First and foremost, the situation at the borders, as described above, is approaching a human rights crisis, and this will only increase as new technologies and cooperation mechanisms are implemented. Human rights protections are needed to prevent further human misery, provide a clear mandate for public officials to take action and for rights holders to hold duty bearers accountable. Further, destination states have obligations under international and regional human rights law to protect the human rights of all people in their territory or under their control. Finally, as the United Nations Secretary General has recently observed, human rights must be placed at the center of the criminal justice response to migration, because "existing human rights challenges often form part of the underlying causes of organized crime and illicit trafficking" ([37], para. 68).

This is not to say that human rights law is necessarily at odds with the enforcement of immigration policy; indeed, the principle of sovereignty explicitly recognizes the authority of states to manage their borders and decide who enters and exits. It is also not to say that greater implementation of international human rights law would be an automatic panacea to exclusion, particularly for irregular migrants. The ICRMW displays ambivalence toward migrant workers in an irregular situation, explicitly setting them apart from regular migrant workers in some important respects (such as in terms of their right to freedom of association, housing or health) [38]. Furthermore, even where they exist in law, irregular migrants are often unable to access their rights in practice, because of the very fact of their alienation from the majority community [39].

Having said that, the human rights framework does constrain certain State behavior by providing an extensive baseline of protection for all persons, regardless of their legal status or their manner of 
arrival. It guarantees minimum standards of protection from arbitrary and unlawful treatment and in respect to fundamental human rights, including economic, social and cultural rights. It is relevant to the situation of migrants who are exploited or coerced in their movement (i.e., who are being trafficked or in a situation akin to trafficking) and migrants who are moving with the facilitation of third parties in an irregular manner, but with no attendant abuse emanating from the facilitator. The following are some of the key standards that must inform State policy-making at borders.

\subsection{Non-discrimination}

A core principle established by international human rights law is that of non-discrimination. The international bill of human rights is unequivocal in extending human rights protection to "all" and to "everyone", with limited exceptions. International human rights law narrowly restricts the circumstances in which states may legitimately permit differences of treatment between citizens and non-citizens, such as the right to vote and take part in public affairs [40]. States may also restrict the freedom of movement of persons who are not lawfully present within the country [41].

However, the Human Rights Committee, which oversees the ICCPR, has made clear that these exceptions are limited and that, in general, a foreigner may enjoy the protection of civil and political rights "even in relation to entry or residence... when considerations of non-discrimination, prohibition of inhuman treatment and respect for family life arise" [42]. According to the principle of non-discrimination, all migrants, regardless of their legal status, motivation for moving, how they arrive at the border, where they come from or what they look like, are entitled to enjoy their fundamental human rights once they are within the territory or jurisdiction of the receiving state.

States are further obliged to ensure that any differential treatment is undertaken for a legitimate objective and is proportionate and reasonable. National origin is an expressly prohibited ground of discrimination in all universal human rights instruments that contain a non-discrimination provision. Human rights law and mechanisms have further determined that nationality and legal status are prohibited grounds of discrimination. See Article 7 of the ICRMW, which includes nationality as a prohibited ground. In addition, the Committee on the Elimination of Racial Discrimination has stated that states must "ensure immigration policies do not have the effect of discriminating against persons on the basis of race, color, descent, or national or ethnic origin". Furthermore, "differences of treatment based on citizenship or immigration status will constitute discrimination if the criteria for different treatment, judged in the light of the objectives and purposes of the Convention, are... not applied in pursuit of a legitimate aim or are not proportional to its achievement" [43]. In other words, border control measures cannot simply discriminate against migrants simply on the basis of their non-citizen or immigration status.

Adopting the principle of non-discrimination would have significant implications for State policies of detention of non-nationals and would prevent violent removal procedures, simply because he is a "third country national" from an unfavorable part of the world or because she lacks a valid visa to enter.

\subsection{Due Process}

Regardless of the size of the migratory "flow" that arrives at borders, each individual has unique protection needs. A recent decision of the European Court of Human Rights has concluded that there is 
a universal due process right of everyone to have an individualized determination of their situation, their reasons for entry and their defense against expulsion. This due process right ensures that all applicable grounds under international law and national law that may negate the expulsion of that particular individual are duly considered, including, but not limited to, the prohibition of refoulement [44]. This, in turn, implies that any immigration decision made at international borders requires a prior reasonable and objective examination of the particular circumstances of each individual's case, and states would be required, therefore, to institute effective screening processes at air, sea and land borders for all migrants. Some migrants will need the protection offered by specific legal regimes, such as refugee law or the protection of victims of trafficking. Others will need the protection of universal human rights norms that protect all persons regardless of their status.

Under international human rights law, all children are entitled to measures determined to be in their best interest, regardless of whether they are unaccompanied or with their parents, whether they are asylum-seekers or irregular migrants. Further, all migrants are entitled to their right to health on a non-discriminatory basis regardless of their legal status. At the same time, border policies should recognize the different situations and needs of migrants. For example, the mental health and other needs of victims of torture will be different from the health needs of migrants who have undergone a long sea voyage. A right to due process limits the ability of states to treat migrants as a collective and, instead, requires individualized assessment. In practice, to establish the risks, vulnerabilities and situation of each migrant, a human rights-based screening and identification system at borders is required.

\subsection{Non-refoulement and Prohibition of Collective Expulsion}

The principle of non-refoulement is key to assessing state decisions about entry and stay. This principle bars states from returning any person, regardless of nationality, status or other grounds, to a place where they would be at risk of torture (Article 3 of the Convention against Torture and, in the case of refugees, Article 33 of the 1951 Convention relating to the Status of Refugees). The ICCPR further provides that all migrants, regardless of their legal status, have the right to protection from arbitrary or unlawful expulsion.

Protection from refoulement must also be applied according to the principle of non-discrimination. It should be noted that the principle of non-refoulement, which widely is recognized as a rule of customary international law, is equally applicable to all places where the intercepting state exercises jurisdiction and control, including on the high seas.

The concept of non-refoulement has been extended to encompass violations of the right to life, including extrajudicial execution, as well as protection from arbitrary detention. The European Court of Human Rights has also held that a state expelling a person to a country where he or she risks being subject to destitution, which reaches the level of inhuman or degrading treatment, would breach its obligations under the principle of non-refoulement [45].

The absolute prohibition of collective expulsion is well established in international and regional human rights law. In its interpretation of Article 13 of the ICCPR, the Human Rights Committee (CCPR) has confirmed that "laws or decisions providing for collective or mass expulsions" would entail a violation of Article 13 ICCPR [42]. The Inter-American Commission has further elaborated 
that "[a]n expulsion becomes collective when the decision to expel is not based on individual cases but on group considerations, even if the group in question is not large" [46]. The International Convention on the Protection of the Rights of All Migrant Workers and Members of their Families provides that "[m]igrant workers and members of their families shall not be subject to measures of collective expulsion. Each case of expulsion shall be examined and decided individually." Article 4 of Protocol 4 to the European Convention on Human Rights similarly provides that "[c]ollective expulsion of aliens is prohibited."

\subsection{The Human Rights-Based Approach}

In order to "translate" the international legal framework into practical guidance for State action, the human rights-based approach has been posited as a useful methodology within which to frame the various protection situations that arise at borders. The human rights-based approach is founded on the interrelated principles of non-discrimination, meaningful participation, empowerment and accountability. It constitutes a framework of action, as well as a set of guidelines and tools for policy makers. Using a human rights-based approach will therefore enable policy makers to identify and properly assist vulnerable individuals and groups at borders, promote their empowerment, enable their participation and ensure that all actions are non-discriminatory in purpose and effect.

Human rights are legal guarantees that protect individuals and groups against actions and omissions, primarily by states, but also extending to other stakeholders that interfere with fundamental freedoms, entitlements and human dignity ([47], p. 3). Under international law, states assume obligations and duties to respect, protect and fulfil human rights. The obligation to respect means that states must refrain from interfering with or curtailing the enjoyment of human rights. The obligation to protect requires states to protect individuals and groups against human rights abuses. The obligation to fulfil means that states must take positive action to facilitate the enjoyment of basic human rights.

As well as changes at the policy level, the human rights approach requires that laws and policies be enforced, and that individuals are held accountable for violations. Improved access to justice for those who suffer harm at the border is essential to providing remedies and upholding human rights. It is crucial that states eliminate impunity for violations against the human rights of migrants at borders, whether perpetrated by State or non-State actors. This includes ensuring that effective mechanisms are in place to enable victims of crimes to testify against perpetrators without being deported or fearing deportation and ensuring legal aid and interpretation services at borders.

\section{Conclusions}

Evidence suggests that the majority of migrants in an irregular status in major destination states entered that states legally, but subsequently overstayed or breached the conditions of their permit. For example, in 2005, the Global Commission on International Migration estimated that a relatively few 2.5 to four million migrants (out of the global total then of around 200 million migrants) cross international borders without authorization every year [48]. Further, experts have noted a lack of evidence that punitive immigration laws deter irregular migrants and asylum-seekers ([29], para. 8). Nevertheless, states are deeply attached to tougher border controls and stricter enforcement as the 
magic bullet to maintain the integrity of migration regimes. As we have seen, this is leading to a human rights crisis at international borders.

Sustained and negative media coverage of migration in host countries (linking irregular migration with notions of illegality, crisis, controversy and government failure) has inter alia encouraged restrictive border control policies. As the Special Rapporteur on contemporary forms of racism, racial discrimination, xenophobia and related intolerance has noted, "The leitmotif of foreigners as criminals, revived on the occasion of many votes, punctuated by political discourse and exaggerated by certain media, increasingly penetrates the collective mentality and gives legitimacy not only to identity-related tensions hostile to cultural diversity, but also to discriminatory and arbitrary behavior by members of certain State bodies" [49]. Public expressions of xenophobia, whether in the form of violence or inflammatory media rhetoric, can be used by governments to justify increasing restrictions in relation to migration, closing down legal channels to entry and stepping up expulsion.

The political will of states to protect, respect and fulfil the human rights of all migrants who travel to their borders is, therefore, lacking. Many states, often led by the popular media and right-wing political figures, resist initiatives that could or could be seen to diminish the sovereign and unfettered right of states to make and apply immigration policy. This resistance is bolstered by national, and also transnational, discourses of security, counter-terrorism and public safety. A deficit in political will is perhaps the hardest gap to fill, but advances can be made through rights-based advocacy and technical assistance at all levels, particularly to raise the awareness of governments, politicians, the media and the wider public of the human rights, contributions and situation of migrants. To this end, the Office of the High Commissioner for Human Rights has begun to draw up principles and guidelines on human rights at international borders in order to assist states to uphold their obligations under international law when making and implementing border control policy. They aim to support states in fulfilling the legal obligations they have voluntarily undertaken and offer recommendations and guidelines with a view to translating the international human rights framework into practical measures in border governance approaches and ensuring that measures taken to address irregular migration, smuggling, and other cross-border phenomena do not violate human rights.

The UN Secretary General recently observed that "international efforts to meet the threat of illicit cross-border trafficking and movement cannot be limited to hardening borders and strengthening law enforcement capacities. Instead, effectively addressing these threats requires multidisciplinary responses that integrate rule of law, development, human rights, social and security approaches, involving all sectors of government and society at the national and international levels." His report ended with a plea to states to establish a balance that ensures both the freedom and the protection of the individual, as well as public safety and well-being ([37], para. 83 and 96). To meet the growing human rights crisis at international borders, all stakeholders must agree and implement a human rights-based approach to the governance of international migration.

\section{Acknowledgements}

The authors would like to acknowledge the generous contributions of all participants at the OHCHR-GAATW expert meeting on the subject of "Human Rights at International Borders: Exploring Gaps in Policy and Practice", held in Geneva on 22-23 March 2012. This article is written 
in the authors' personal capacity and does not necessarily reflect the views of the United Nations or GAATW.

\section{Conflict of Interest}

The authors declare no conflict of interest.

\section{References and Notes}

1. Didier Bigo. "Criminalisation of Immigrants: the side effect of the will to control the frontiers and the sovereign illusion." In Irregular Migration and Human Rights, Theoretical, European and International Perspectives. Edited by Barbara Bogusz, Ryszard Cholewinski, and Erika Szyszczak. Leiden: Martinus Nijhof, 2004, 61-93.

2. Stephen Castles, and Mark J. Miller. The Age of Migration: International Population Movements in the Modern World, 4th ed. Hampshire: Palgrave Macmillan, 2009.

3. United Nations Secretary General. Report of the Secretary General on Illicit Cross-Border Trafficking and Movement, S/2012/777. Geneva: United Nations Security Council, 19 October 2012.

4. Pia Oberoi. "The enemy at the gates and the enemy within: Migrants, social control and human rights." In Project on Social Control and Human Rights. Geneva: International Council on Human Rights Policy, 2009.

5. More information on this consultation, including background papers and informal summary conclusions, can be found at Office of the High Commissioner for Human Rights, OHCHR Expert consultation of Human Rights at International Borders: Exploring Gaps in Policy and Practice, 22-23 March 2012. Available online: http://www.ohchr.org/EN/Issues/Migration/Pages/ OHCHRExpertconsultationExploringGapsinPolicyandPractice.aspx (accessed on 30 July 2013).

6. Council of Europe: Commissioner for Human Rights. "Recommendation of the Commissioner for Human Rights Concerning the Rights of Aliens Wishing to Enter a Council of Europe Member State and the Enforcement of Expulsion Orders." Comm DH/Rec(2001). Strasbourg: Council of Europe, 19 September 2001. Available online: https://wcd.coe.int/ViewDoc.jsp?id=980219 (accessed on 30 July 2013).

7. Principals of the Global Migration Group. "Statement of the Global Migration Group on the Human Rights of Migrants in Irregular Situations." Geneva, 30 September 2010. Available online: http://www.ohchr.org/EN/NewsEvents/Pages/DisplayNews.aspx?NewsID=10396\&LangID=E (accessed on 19 July 2013).

8. Francois Crépeau, Special Rapporteur on the Human Rights of Migrants. "Regional study: Management of the external borders of the European Union and its impact on the human rights of migrants." A/HRC/23/46. Report presented to the United Nations Human Rights Council, 23rd Session, Geneva, Swizerland, 24 April 2013.

9. Lesley Wexler. "The role of human rights in migration regional consultative processes." American Society of International Law 106 (2012): 65-67.

10. Mark Salter, and Can Mutlu. Asymmetric Borders: The Canada-Czech Visa War and the Question of Rights. Brussels: Center for European Policy Studies, 2010. 
11. “The Fallacy of 'Enforcement First'.” Immigration Policy Center, 9 May 2013. Available online: http://www.immigrationpolicy.org/just-facts/fallacy-enforcement-first (accessed on 28 July 2013).

12. "Field Testing: CLOSEYE Project puts Drones over the Mediterranean." Statewatch News Online, 10 May 2013. Available online: http://www.statewatch.org/news/2013/may/02eu-dronesmediterranean.html (accessed on 30 July 2013).

13. Reuters. "Bosnia, Croatia Battle Human Smuggling." NBC News, 15 May 2013. http://www.nbcnews.com/id/51892907/ns/world_news-mideast_n_africa/\#.UZa7y4JAvEU.

14. See e.g., Gallya Lahav. "The Rise of Nonstate Actors in Migration Regulation in the United States and Europe: Changing the Gatekeepers or Bringing Back the State." In Immigration Research for a New Century: Multidisciplinary Perspectives. Edited by Nancy Foner, Ruben Rumbaut and Steven Gold. New York: Russell Sage Foundation, 2000.

15. Andrew Brouwer, and Judith Kumin. "Interception and Asylum: When Migration Control and Human Rights Collide." Refuge 21, no. 4 (2003): 9.

16. Claire Brolan. "An Analysis of the Human Smuggling Trade and the Protocol against the Smuggling of Migrants by Land, Air and Sea (2000) from a Refugee Protection Perspective." International Journal of Refugee Law 14, no. 4 (2003): 57.

17. Europol. EU Serious and Organized Crime Threat Assessment. The Hague: Europol, 28 April 2011.

18. United Nations High Commissioner for Human Rights. The Situation of Migrants and Asylumseekers Fleeing Recent Events in North Africa: Report of the United Nations High Commissioner for Human Rights, A/HRC/18/54. Geneva: Human Rights Council, 1 September 2011.

19. OWNI.eu. "Fortress Europe: A Deadly Exodus." Available online: http://owni.eu/2011/03/04/ app-fortress-europe-a-deadly-exodus/ (accessed on 19 July 2013).

20. Medecin Sans Frontiers. "Sexual Violence and Migration: The Hidden Reality of Sub-Saharan Women Trapped in Morocco en route to Europe." Briefing Paper. Geneva: Medecins Sans Frontiers, March 2010. http://www.doctorswithoutborders.org/publications/reports/2010/MSFsexual-violence.pdf.

21. Kristy Siegfried. "Europe's Forced Returnees Claim Abuse." IRIN News, 10 April 2013. http://www.irinnews.org/report/97815/europe-s-forced-returnees-claim-abuse.

22. Human Rights Committee. "General Comment No. 8 on the Right to Liberty and Security of the Person.” HRI/GEN/1/Rev.9 (Vol. I). Geneva: Switzerland, 27 May 2008.

23. Summary Conclusions of the Global Roundtable on Alternatives to Detention of Asylum-Seekers, Refugees, Migrants and Stateless Persons: Geneva, 11-12 May 2011. Geneva: OHCHR and the United Nations High Commissioner for Refugees, July 2011. Available online: http://www.ohchr.org/EN/Issues/Migration/Pages/Roundtable.aspx (accessed on 19 July 2013).

24. Bernard Harcourt. "Muslim Profiles Post-9/11: Is Racial Profiling an Effective Counter-Terrorist Measure and Does it Violate the Right to be Free from Discrimination?" In Security and Human Rights. Edited by Benjamin Goold, and Liora Lazarus. Portland: Hart Publishing, 2007, 73-98.

25. "Migrants by orgin and destination: The role of South-South migration." Population Facts, No. 2012/3. New York: UN Department of Economic and Social Affairs, Population Division, June 2012. 
26. See Craig Kennedy, et. al. Transatlantic Trends Survey: Immigration. Brussels and New York: Transatlantic Trends, 2010. http://trends.gmfus.org/files/archived/immigration/doc/TTI2010_ English_Key.pdf.

27. World Migration Report 2011: Communicating Effectively About Migration. Geneva: International Organization for Migration, 2012. http://publications.iom.int/bookstore/free/ WMR2011_English.pdf.

28. Working Group on Arbitrary Detention. "Report of the Working Group on Arbitrary Detention." UN Doc. A/HRC/7/4. Report presented at the Human Rights Council, 7th Session. Geneva, January 2008.

29. François Crépeau. "Report of the Special Rapporteur on the Human Rights of Migrants." UN Doc. A/HRC/20/24. Report presented at the Human Rights Council, 20th Session. Geneva, April 2012.

30. François Crépeau. "Statement of the Special Rapporteur on the Human Rights of Migrants." Report to the 66th Session of the General Assembly, Third Committee-Item 69 (b), (c). New York, 21 October 2011.

31. Anna Verley Kvittingen. Negotiating Childhood: Age Assessment in the UK Asylum System. Working Paper Series, No. 67. Oxford: Refugee Studies Centre, University of Oxford, November 2010.

32. Irregular Migration, Migrant Smuggling and Human Rights: Towards Coherence. Geneva: International Council on Human Rights Policy (ICHRP), 2012.

33. Gabriela Rodriguez Pizarro. "Report of the Special Rapporteur on the Human Rights of Migrants." U.N. Doc. E/CN.4/2000/82. Report presented to the UN Commission on Human Rights, 56th Session. Geneva, 6 January 2000.

34. Khalid Koser. "The Smuggling of Refugees." In Global Human Smuggling: Comparative Perspectives, 2nd ed. Edited by David Kyle and Ray Koslowski. Baltimore: The John Hopkins University Press, 2011.

35. Katherine Corcoran. "In Mexico, X-Ray machines expose the growing business of migrant smuggling." Associated Press, 20 May 2011.

36. Eleanor Taylor-Nicholson, and Pia Oberoi. "Background Paper." Paper presented at the OHCHR and GAATW Expert Consultation on Human Rights at International Borders: Exploring Gaps in Policy and Practice, Geneva, 22-23 March 2012. http://www.ohchr.org/Documents/ Issues/Migration/Events/HumanRightsatInternationalBorders_backgroundpaper2012.pdf.

37. United Nations Secretary-General. Report of the Secretary-General on Illicit Cross-Border Trafficking and Movement, S/2012/777. Geneva: United Nations Security Council, 19 October 2012.

38. Linda Bosniak. "Human Rights, State Sovereignty, and the Protection of Undocumented Migrants under the International Migrant Workers Convention." In Irregular Migration and Human Rights: Theoretical, European and International Perspectives. Edited by Barbara Bogusz, Ryszard Cholewinski, Adam Cygan and Erica Szyszczak. Leiden: Martinus Nijhoff Publishers, 2004.

39. Gregor Noll. "Why Human Rights Fail to Protect Undocumented Migrants." European Journal of Migration and Law 12 (2010): 241-72.

40. International Covenant on Civil and Political Rights, Article 25, 16 December 1966.

41. International Covenant on Civil and Political Rights, Article 12, 16 December 1966. 
42. Human Rights Committee. "CCPR General Comment No. 15: The Position of Aliens Under the Covenant." Adopted at the 27th Session of the Human Rights Committee, Geneva, April 1986.

43. The Committee on the Elimination of Racial Discrimination. "General Recommendation No. 30: Discrimination against Non Citizens." UN Doc. CERD/C/64/Misc.11/rev.3 (2004). Adopted at the 64th Session of the CERD Committee, October 2004, paras. 4 and 9.

44. Hirsi et al v Italy: Intervener Brief Filed on Behalf of the United Nations High Commissioner for Human Rights. Geneva: United Nations Office of the High Commissioner for Human Rights, 5 May 2011. http://www.ohchr.org/EN/Issues/Migration/Pages/StudiesAndReports.aspx (accessed on 19 July 2013).

45. "M.S.S. v Belgium and Greece. ECtHR Application No. 30696/09." Judgement. Belgium and Greece: Council of Europe: European Court of Human Rights, 21 January 2011.

46. "Inter-American Commission on Human Rights." OEA/Ser.L/V/II.116, Doc. 5, rev. 1 corr. Report on Terrorism and Human Rights. Washington: Organization of American States, OAS Doc., October 2002.

47. "Human Rights, Terrorism and Counter-terrorism." Fact Sheet No. 32. Geneva: OHCHR, July 2008.

48. Global Commission on International Migration. "Migration at a Glance, 2005." Global Commission on International Migration (GCIM), 1 October 2005. http://web.mnstate.edu/ robertsb/308/Migration $\% 20$ at $\% 20 a \% 20$ glance.pdf.

49. Doudou Diène. "Updated study by the Special Rapporteur on contemporary forms of racism, racial discrimination, xenophobia and related intolerance: Political platforms which promote or incite racial discrimination." U.N. Doc. A/HRC/5/10. Report presented to the Human Rights Council, 5th Session. Geneva, 25 May 2007.

(C) 2013 by the authors; licensee MDPI, Basel, Switzerland. This article is an open access article distributed under the terms and conditions of the Creative Commons Attribution license (http://creativecommons.org/licenses/by/3.0/). 